During the past year, observations have become available from astrophysical and space research which confirm predictions of this general theory in some detail.

The application of electrical discharge theory to explain a well-known type of stellar spectrum sug. gested the existence of spiral nebulæ on a stellar scale. Photographic evidence of the existence of such nebulæ has become available. The theory explains the general form of the planetary nebulæ and of the gas movements observed in them.

Evidence in support of another prediction has resulted from satellite observations by U.S. naval scientists. The observations of $80,000-V$. X-rays associated with solar flares implies the existence of temperatures of about $100,000,000^{\circ} \mathrm{K}$. in solar atmospheric electrical discharges. The prediction that such temperatures must exist in this region was made from electrical discharge theory applied to magnetic storms.

Another interesting by-product of theoretical work in a different field is a new method of measuring the surface tension of a clean surface in a liquid. This results from the mathematical solution of the problem of the equilibrium shapes of bubbles in electrical and centrifugal fields which was required in a study of the electrical breakdown of liquids, itself part of an investigation on breakdown of highly stressed impregnated dielectrics.
The most notable addition, during the year, to the Association's experimental resources has been the building and equipping of a Creep Testing Laboratory, intended to accelerate the important investigations on the creep behaviour of steels for use at temperatures above $1,050^{\circ} \mathrm{F}$. $\left(565^{\circ} \mathrm{C}\right.$.).

At the end of the year under review a major reorganization of the Association's committee structure was put into effect. Six divisional committees now guide and superintend the Association's work, replacing twenty-two sectional committees and eighty-one research committees.

An interesting reference is made to the desirability of fostering still closer relations between the Association and the universities and technical colleges. Through its extra-mural programmes the Association already maintains close contact with quite a number of departments in universities and technical colleges. To supplement this, special facilities were instituted to provide for all universities and technical colleges in the Commonwealth obtaining ${ }^{+}$he published reports of the Association. A further step has now been taken in the development of this policy in that professors of electrical engineering and heads of electrical engineering departments in technical col. leges have been invited to apply for associateship of the British Electrical and Allied Industries Research Association with full membership benefits.

J. Greig

\title{
FOUR DECADES OF STATE FORESTRY IN NEW ZEALAND
}

$\mathrm{T}$ HE annual report of the Director of Forestry in New Zealand for the year ended March 31, 1960, made to Sir Ernera Tirikatene, the Minister of Forests, is full of interest*. Essentially it consists of 37 appendixes in tabular form, from which progress towards various objectives can be measured, if desired. This will be the last report made by Mr. Entrican, who has just retired after long service.

The report is refreshing for its frankness on some of the mistakes made in the past. It does not disguise the difficulties encountered in the somewhat erratic progress being made towards the building up of a sound forestry practice and the creation of areas of managed forest which are expected to make important contributions to the national economy.

The State service is organized into a number of divisions which deal with management, public and private forestry, development, which comprises training and research, protection forestry, engineering work, operations, industrial operations and, finally, commercial operations.

In the past no more than lip service has been paid to the fundamental principle in forestry of sustaining the yield, and in this report we have a plain confession of neglect to adhere to that principle. "Thus", it says, "on a 2,000-acre area to be managed on a 40-year rotation, 50 acres would be planted annually, with the first 50 acres coming to maturity ... in the forty-first year, concurrently with the completion of planting over the whole area." New Zealand speaks thus from bitter experience. The Murupara working circle in the largest planted forest there-Kaingaroa-covers 200,000 acres, the oldest portion of which is 37-47 years of age and * New Zealand, Report of the Director of Forestry for the year
ended 31 March, 1960. Pp. 115. (Wellington: Government Printer, 1960). extends to 10,000 acres only. The next age-class -27-37 years old-covers no less than 150,000 acres, the remaining 40,000 acres being of younger ages. This vast mass of 150,000 acres, composed mainly of Monterey pine (Pinus radiata D. Don) is described as "steadily moving towards maturity en masse". For various reasons it has been found impossible to cope with the tending of this large area and, in respect of other species in which there are fewer natural deaths, the growing-stock is said to be "accumulating towards stagnation". Here there is a lesson for other countries engaging in large-scale afforestation on fertile land.

New Zealand is anxiously trying to find an outlet for what is frankly called its second-grade timber as a pulp-wood, having produced an excess of certain assortments. An export trade to Australia has been established, but New Zealand openly looks ahead to supplying pulp and paper wood to the rapidly developing populations of the Asiatic countries. A strong plea is made for increasing the area of plantations of exotic conifers, even on good farming land, to produce timber for export, and it is the producer of not enough butter-fat per acre-not of mutton and wool-that is being urged to switch over to forestry. Farmers are asked to plant trees extensively, even to the extent of providing one out of the three million acres of the prescribed afforestation programme, which is expected to increase the area of planted exotic trees to $3,000,000$ acres by the year 2025 .

Unlike Great Britain, New Zealand still has a large area of indigenous forest. In 1840 the area there covered by these must have amounted to about two-thirds of that of the whole country. Since then they have been considerably reduced. Their treatment has followed the usual Anglo-Saxon pattern of 
unplanned clearance for farming and of devastation, and exploitation goes steadily on. At one time no thought was given to its conservation as forest, and various arguments were put forward which contributed towards its neglect. Impossibility of regenerating some of the species was one which is now being proved to be without foundation. The main contributing factor was probably the ease and assumed success with which the early exotic plantations were begun. Ironically, one authority has said recently that "the indigenous forest will serve to tide over any crisis arising out of the destruction of the exotic plantations by widespread epidemics of insects and disease".

Immense areas of the natural forests on the mountainous watersheds of the major rivers have been devastated. Browsing by animals in these areas leads to loss of tree cover followed by erosion and devastating flooding in the rich settled lowland country. In a vast area of more than two million acres of ratakamaki protection forest in the South Island, disastrous results of browsing by opossums, deer and chamois are predicted. In the Waimakariri River catchment area sheep are "slowly making a desert land by close cropping of vegetative cover and expos. ing the soil to erosion", and threatening the city of Christchurch with possible catastrophe by floods.

The division of protection forestry of the service is responsible for the control of noxious animals, on which nearly $£ 312,000$ was spent during the year. In official operations during the year 31,494 deer, 24,830 goats and 4,920 chamois were killed and it is claimed that a bounty was paid in respect of $1,106,000$ opossums destroyed.

Not all the new exotic plantations have been made on deep volcanic soils. In one forest in South Island an area of 3,500 acres was blown over by wind on a shallow soil, where, owing to rooting difficulties, the trees appear to be unable to stand after reaching a height of $50 \mathrm{ft}$. This sort of thing is also very liable to happen in Great Britain.

The New Zealand report faces up to another forestry problem, namely, that of putting timber grown in remote areas on the market. The costs have been found to be so high that they are used as a strong argument that farmers and others should grow trees nearer centres of consumption and should exploit and convert them there. This runs counter, however, to any policy which seeks to establish, or maintain, a healthy rural population.

The future of forestry in New Zealand is looking more hopeful for two main reasons. The first is that forest management, though still very backward when compared with some European countries, is being given more attention. Management plans, which are "forest regulations prescribing the application of certain sylvicultural rules, and the execution of certain works to produce a definite result", now apply to no less than $3,080,000$ acres of the indigenous forest. The definition of the objects for which each forest is to be managed is a matter of vital importance and the progress made recently is heartening.

The second reason is that great stress is at last being laid on the need for research in forestry. There is now a large staff of workers so engaged, and the Forest Research Institute at Rotorua publishes its own report, which is rather voluminous, and describes work on a wide variety of subjects. It is gratifying to see that attention since 1956 has been directed to the study of the indigenous forest, which may be a dangerous concept, but is a very significant reality in New Zealand, from which very important lessons can be learnt.

\section{THE CASE FOR A NEW PROFESSION*EMBRACING SCIENCE, LIBRARIANSHIP AND FOREIGN LANGUAGES}

\begin{abstract}
A
SURVEY*, supported by the National Science Foundation and sponsored by the Modern Language Association of America, and carried out under sub-contract with the latter Association as part of a contract with the United States Office of Education, Department of Health, Education and Welfare, argues the case for a new profession concerned with the handling of scientific information, librarianship and foreign languages. Its six chapters delineate first the characteristics of this new profession and the influences which have determined its emergence; the snares and problems of recruitment; undergraduate and graduate education in relation to the supply of such recruits; professional training; and the nature of the professional support which is required, in which connexion the authors recommend establishment of an advisory board to devise an appropriate well co-ordinated programme of courses, seminars, research groups or short-time institutes for training those already engaged in the profession or proposing to enter it. There are numerous detailed recommendations, many of which are applicable in Great Britain also, but although Messrs. L. Cohen

* Science Information Personnel: The New Profession of Information Combining Science, Librarianship and Foreign Language. By Leonard Cohen and Kenneth Craven. Pp. vi + 74. (New York: dollars.
\end{abstract}

and $\mathrm{K}$. Craven lean towards the formation of a professional body, they are not explicit on the point and do not recognize the difficulties inherent in the presence of corporate bodies and individual practitioners which have, in Great Britain, considerably hindered the development of a really strong and representative professional qualifying body.

Some of the recommendations are directed towards management, for example, those relating to salary structure, status and standards. The contribution of the scientist is recognized in recommendations relating to co-operation and mutual understanding between scientists as such and those engaged in information work. Recommendations relating to undergraduate facilities stress the importance of at least two foreign languages, a broad liberal arts education and a major course in a scientific discipline for those entering on scientific information work. Establishment of a graduate school of science information leading to a master's degree is recommended as well as research leading to the establishment of a doctoral programme in this field and the growth of specialized information centres at the universities. They also recommended that technical institutions should explore the needs of industry and government for technicians in special libraries and science information centres and offer appropriate 